UDC 278.6.018:629.3!18/19»(477)(09)

DOI https://doi.org/10.37915/pa.vi49.279

Binytska K. M. *,

orcid.org/0000-0002-2111-5275

Nahorniy Ya. V. ,

orcid.org/0000-0003-2381-2194

Zahorodnia A. A. ,

orcid.org/0000-0003-2418-1670

\title{
DEVELOPMENT OF THE SYSTEM OF PROFESSIONAL TRAINING OF THE FUTURE TRANSPORT SPECIALISTS IN EDUCATIONAL INSTITUTIONS OF UKRAINE (LATE XIX - EARLY XX CENTURIES)
}

The article on the basis of theoretical generalizations considers the main aspects of the development of the system of professional training of the future specialists of the transport industry in educational institutions of Ukraine in the late XIX - early XX centuries.

The retrospective analysis of the development of professional training of the future specialists for the transport industry in Ukraine in the late XIX - early XX century was conducted on the example of the most progressive and highly paid at the time specialties in this sphere, namely: training of maritime specialists and railway workers.

We found out that the period of the end of the XIX - 1917 is the time of creation of educational institutions for the training of the future specialists in maritime affairs. Thus, in the late XIX - early XX century there were more than 20 educational institutions in Ukraine, which provided training for the future sailors for the military and commercial fleet in the Black Sea. During this period, one of the key links in vocational education were maritime schools and long-distance sailing schools, in particular in the Kherson province, they were located in the cities of Beryslav, Oleshky and Hola Prystan, as well as Kherson. It is generalized that in the period of 1921-1941 the professional training of the future specialists for the fleet was done in corps (schools), in which the priority direction of professional training was defined as wide universalization.

It is generalized that the development of railway transport took place in connection with the construction of the Kursk-Kharkiv-Azov railway in Slobozhanshchyna, which in turn needed qualified specialists of various professions who somehow interact with this industry. As a result, Kharkiv, an important railway junction, soon became a training center for the future railway specialists. Therefore, on December 1, 1870 at the station of Kharkiv opened a railway school for the training of technicians, which was reorganized into the Kharkiv Technical Railway School. In 1917, the Kharkiv Technical Railway School was reorganized into a Secondary Railway Vocational School. On its basis in 1921 the Kharkiv technical school of ways of a combination of a mechanical specialty with a four-year course of training was created.

On its basis in 1921 the Kharkiv technical school of ways of connection of the mechanical specialty with a four-year course of training was created.

In 1920, the Operational Technical School for the training of operational specialists was opened at the Southern Railway.

On April 1, 1926, specialist training courses for engineers began to function in Kharkiv. On August 17, 1927, they were renamed into the Higher Technical Courses of the People's Commissariat of Railways in Ukraine.

*C Binytska K. M.

*C) Nahorniy Ya. V.

*C Zahorodnia A. A.

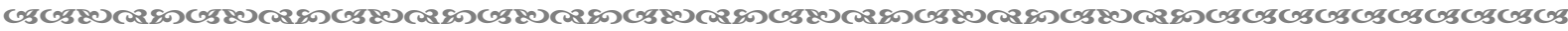


जs ПЕДАГОГІЧНИЙ АЛЬМАНАХ. - 2021. - ВИПУСК 49

os

In 1929, three railway technical schools (Technical School of Mechanical Railways, Operational Technical School and Evening Workers' Mechanical Technical School) were merged into one professional technical institution - Kharkiv United Technical School of Railways.

In the late 1920-s - early 1930-s the economy of the USSR gained momentum, but the transport industry did not keep up with the high rate of industrial development. Therefore, on March 23, 1930, the Kharkiv Institute of Railway Engineers began its work. Already in 1940-1941 academic year it became one of the largest railway institutions of higher education in the USSR.

Thus, the retrospective analysis of the activities of educational institutions that provided training for the future transport professionals showed that during the period (late XIX - early XX century), in connection with the development of scientific and technological progress in society there was a need to train qualified future maritime specialists and railway workers. During this period, educational institutions were established, which actively developed in the system of professional training of transport specialists.

Key words: professional training, future specialists, transport industry, sailors, railway workers.

The statement of the issue. The reforms taking place in the education system of Ukraine are determined by information, technological and economic transformations in society. Given that the transport industry is one of the powerful resources for the development of the Ukrainian state and society, it is of particular strategic importance to ensure a high-quality national system of training of transport professionals. And although its modernization consists, first of all, in the advanced nature of the system development, it is important to study and take into account the historical experience of formation and development of the system of professional training of the future specialists in the transport industry. Thus, the study of the historical aspect of the problem of the system of professional training of the future specialists in the transport industry in educational institutions of Ukraine is, in our opinion, relevant.

The purpose of the article. is a retrospective analysis of the main aspects of the development of the system of professional training of the future specialists in the sphere of transport in educational institutions of Ukraine (late XIX - early XX century).

The analysis of relevant research. Today there are significant developments related to the training of the future professionals for the transport industry in Ukraine. Scientists Zolotovska V. [1], Nahrybelnyi Ya. [3-4], Tymofieieva O. [6], Chornyi O. [7], Sharhun T. [8] consider various aspects of this problem, which also emphasize its relevance for modern vocational education. Despite the significant number of different jobs, the problem of development of the system of professional training of the future specialists in the sphere of transport in educational institutions of Ukraine in the early XX century remains out of the attention of researchers in the historical and pedagogical context, which determines the relevance of our research.

The body of the research. Today there is a need to comprehend the history of training of the future professionals for the transport industry in the context of the development of the system of education [4].

The solution of this problem is possible under the following conditions: actualization of historical achievements of training of transport specialists as an opportunity to predict trends in the training of the future transport specialists; identification of training factors for the future specialists in the transport industry in their dynamics during the study period; determination of specific conditions for training of the future transport specialists in educational institutions, in particular higher ones; appeal to the experience gained in the history of pedagogical thought of training of the future specialists in the sphere of transport in educational institutions and its creative use under modern conditions of higher education institutions [8]. 
In our research we used retrospective analysis, which involves the study of any phenomenon in the process of its origin, formation and development, consideration of pedagogical phenomena in relation to a particular historical epoch, socio-economic features of this era, determining the content, methods and organization of the educational process. Sometimes scientists try to establish direct links between phenomena, facts, views of distant epochs and the present, draw illegal historical parallels, spend time and effort searching for teachers' of the past statements that substantiate modern ideas, refer to concepts and facts from the past, only outwardly similar to modern ones. The fact that many terms and concepts found in the literature of past centuries, for all their similarity to modern ones, had a completely different interpretation and in the course of historical development have significantly changed their meaning is completely ignored. Retrospective analysis of pedagogical phenomena takes into account a number of points, namely: socio-economic features of the era, which determines the content, methods and organization of the educational process, as well as the direction of ways to find their change; influence in each epoch of successes of general scientific progress [8].

Retrospective analysis of the development of professional training of the future specialists for the transport industry in Ukraine in the late XIX - early XX century we will carry out on the example of the most progressive and highly paid specialties at that time, namely: preparation of maritime experts and railwaymen.

Researcher O. Tymofieieva determines the period of the end of the XVIII century - early XX century - is the time of creation of educational institutions for the training of maritime specialists. "This is due to the fact that after the destruction of the Zaporozhian Sich and its flotilla, the Russian Empire began intensive colonization of southern Ukrainian lands. Then the empire began to build the Black Sea fleet and the development of the new sea routes to the markets of Asia and Europe. The majority of the personnel of the new fleet - the Azov and Dnieper flotillas - were Black Sea and former Zaporozhian Cossacks" [6]. In the second half of the XIX - first quarter of the XX century one of the key sections in the professional education of the Kherson region was the maritime schools in Beryslav, Oleshky and Hola Prystan, as well as the Kherson School of Long-distance Sailing. In the short time, they strengthened the material base, staffed with experienced teaching staff, trained high-quality professional sailors [3, p. 4].

Recognizing that the activities of the Black Sea Maritime Educational Institutions of the last quarter of the XVIII - early XX century in Ukraine there were more than 20 educational institutions focused on training sailors for the navy and commercial fleet in the Black Sea [1]. Some of them were created in the South of Ukraine in the first half of the XIX century, when the training of navigators was mainly military in nature. In 1834, given the favorable conditions of location, the first school of merchant shipping in the Ukrainian lands (now the Kherson State Maritime Academy) was established in Kherson. The rules for admission outlined the range of requirements for applicants to study in the newly created institution. Future cadets of the school had to be able to read and write, know the four rules of arithmetic, as well as be strong, without physical defects and brought up "in the fear of God and good morals" [7, p. 12].

In 1921-1941, specialists for the navy were trained in corps (schools), in which the priority of professional training was broad universalization [4].

At a rapid pace in the XIX century another type of transport industry was built and developed, namely the railway connection.

In the late 1860-s the Kursk-Kharkiv-Azov railway was built on the territory of Slobozhanshchyna - one of the first in the territory of Eastern Ukraine. The development of railway transport required qualified specialists of various professions who somehow 
interact with this industry. As a result, Kharkiv, an important railway hub, soon became a training centre for railway workers [5].

Training of railway specialists at the Kharkiv Operational and Traction Institute of Railway Transport is directly related to the activities of secondary railway educational institutions, the operation of which in the Kharkiv region has a long tradition.

December 1, 1870 in Kharkiv opened a railway school for the training of technicians, which was reorganized into the Kharkiv Technical Railway School - at that time one of the first in the Russian Empire. The educational institution trained locomotive drivers, track foremen, as well as telegraph technicians and draftsmen [2].

In 1916, the question of the need for a gradual reorganization of educational institutions for the training of railway specialists was actively discussed. As a result, the idea arose to open the third in the Russian Empire (after Moscow and St. Petersburg) institute of railway engineers, which would annually train and graduate 250 engineers. Thus, in 1916, at the meeting of the Kharkiv City Duma, a proposal was made three times to "take all measures to open a third institute of roads in Kharkiv", and the mayor filed a petition to the Minister of Railways. However, at that time this idea was not realized - it was stopped by the First World War and the revolution [2].

In 1917, the Kharkiv Technical Railway School was reorganized into a secondary railway vocational school. On its basis in 1921 the Kharkiv technical school of ways of connection of mechanical specialty with a four-year course of training was created.

In 1920, the Operational Technical School for the training of operational specialists began work on the Southern Railway. In March 1925, on the initiative of the All-Ukrainian Committee of Trade Unions of Railwaymen, evening working mechanical technical school of the Southern Railway was opened with a four-year term of study. It trained engineers for the repair and operation of locomotives [5].

On April 1, 1926, in Kharkiv in the Southern District of Railways, specialist training courses for engineers began to operate, which were renamed into the Higher Technical Courses of the People's Commissariat of Railways in Ukraine in accordance with the order of the National Commissariat of Railways of August 17, 1927. The number of students was about 100 people consisting of employees of four railways: South, South-West, North-Donetsk and Katerynoslav (Prydniprovsk). The training lasted one year. The first graduation took place in June 1929, after which the graduates were sent to work on the railways and in the apparatus of the National Commissariat of Railways by the heads of services, depots, workshops, and chief engineers of the factories [5].

In 1929, three railway technical schools (Technical School of Mechanical Railways, Operational Technical School and Evening Workers' Mechanical Technical School) were merged into one professional technical institution - Kharkiv United Technical School of Railways with three departments (mechanical, operational and evening). However, the newly formed joint technical school was not able to fully meet the increased needs of the Southern Railway for highly qualified specialists [5].

In the late 1920-s - early 1930-s the economy of the USSR gained momentum, but the transport industry did not keep up with the high rate of industrial development. Therefore, the decision to open a number of railway educational institutions was due to attempts to solve the staffing problem of the industry. The beginning of the Kharkiv Institute of Railway Engineers was determined by two documents: Resolution of the Council of People's Commissars of the USSR of March 23, 1930 [5].

"On the plan for the transition to the unified system of industrial and technical education" and the Letter of the Commissioner of the People's Commissariat of Communications of the USSR under the People's Commissar of the USSR dated July 8, 1930 "On the organization of the beginning of 1930-1931 academic year of Kharkiv Operational and 


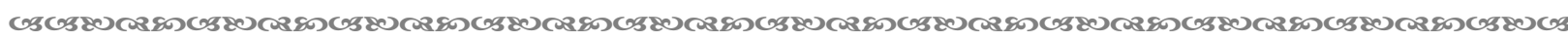
ПЕДАГОГІЧНИЙ АЛЬМАНАХ. - 2021. - ВИПУСК 49

जos

Traction Institute of Railway Transport on the basis of Kharkiv Evening Workers' College" [5].

In the same period, from the beginning of 1930-1931 academic year Kharkiv Road Institute was organized.

On September 1, 1930, the Kharkiv Operational and Traction Institute opened its doors to 432 students. It was the only higher education institution in Kharkiv and one of the few in Ukraine to start the school year on time (on September 18, all students of the new enrolment received scholarships) [5].

Since the beginning of 1931-1932 academic year Higher Technical Courses of the National Commissariat of Railways were included into the structure of the institute. Students of the third enrolment (after the merger of courses) studied in separate groups according to the curricula of the institute, and in 1933 the institute graduated 275 specialists [5].

Since September 1, 1931, in accordance with the order of the Central Department for Personnel Training of the National Commissariat of Railways of the USSR, the correspondence sector was organized within the institute. It operated until January 1934, and part-time students in this sector were transferred to the Kharkiv correspondence department of the All-Union Correspondence Institute of Railway Engineers.

As of January 1, 1932, Kharkiv Institute of Engineering Transport had branches in the cities of Debaltsevo, Dnipropetrovsk, Krasnyi Lyman, Poltava with a total of about 280 students. Workers' faculties were in the cities of Debaltsevo, Izium, Kursk, Krasnyi Lyman, Poltava, Osnova, Novokhopersk, Lysky, Rossosha, Rodanovo, Kharkiv, in which 1592 people studied [5].

From July 1932 to December 1933, the institute was called the Kharkiv Operational and Mechanical Institute of Railway Engineers. In 1934 it was renamed to the Kharkiv Institute of Railway Engineers [5].

In the summer of 1934, in connection with the transfer of the capital of Ukraine from Kharkiv to Kyiv, the Kyiv Railway Institute, established on June 12, 1930, as well as its five working faculties: Birzulyn, Haivoron, Kyiv, Korosten and Koziatyn were included to the Kharkiv Institute of Railway Engineers.

In October 1934, two workers' faculties from the Dnipropetrovsk Institute of Railway Engineers entered the Kharkiv Institute of Railway Engineers: in the cities of Luhansk and Popasna. Thus, as of January 1935, 14 workers' faculties were subordinated to the Kharkiv Institute of Railway Engineers [5].

Since September 1936, all workers' faculties were liquidated, except for Krasnyi Lyman and Kharkiv, with day and evening departments, which lasted, respectively, until June 1937 and September 1941.

As a result of the merger of the two Kharkiv and Kyiv institutes in 1934, the number of Kharkiv Institute of Railway Engineers students in comparison with 1933-1934 academic year increased from 961 to 1947 people. Since September of the same year, the combined Kharkiv Institute of Railway Engineers has had three full-time faculties: mechanical, operational and engineering-economic, as well as the evening department and the Kyiv branch [5].

On February 16, 1936, in accordance with the Resolution of the Central Executive Committee of the USSR, the institute was named after Serhii Myronovych Kirov. At the same time, the organization of the educational process in the Kharkiv Institute of Railway Engineers in the early 1930-s was in the unsuitable state for a higher education institution, as noted in the annual reports, "at the technical school level". The reasons for this situation were: lack of qualified teaching staff, low theoretical level of teaching special disciplines, simplification of project work and so on. The government decree of April 29, 1934 described the composition of the teaching staff of the institute as follows: 
The most acute personnel problem for the newly established institute was solved in several ways: well-known specialists from other institutions of higher education and production were invited, at the same time, teachers who had already worked at Kharkiv Institute of Railway Engineers improved their skills and received academic titles [5].

In 1934, 316 students studied at the institute at the operational faculty, 448 at the mechanical faculty, and 197 at the evening faculty. In terms of social status, the largest number of students were workers $-65.9 \%$, employees $-31 \%$, peasants $-3.1 \%$.

During 1930-1944, the Kharkiv Institute of Railway Engineers had two main faculties operational and mechanical, namely: locomotive, traffic and freight.

The school trained specialists in the following specialties: "Operation Engineer", "Economist Engineer", "Locomotive Mechanical Engineer", "Freight Engineer of Mechanical Engineering" and "Locomotive Repair Mechanic Engineer" (at the evening faculty) [5].

The educational process consisted of lectures, group classes (which took the largest number of hours), design, laboratory classes. In 1938-1939 academic year old curricula in special disciplines were withdrawn, and work was carried out on the new programs developed by the relevant departments. The staffing system began to function, thanks to which the teaching staff was significantly strengthened and the preconditions for their professional development were created.

During the 1930-s, nine laboratories were established at the Kharkiv Institute of Railway Engineers: physical, chemical, thermal, mechanical testing of materials, metallographic, electrical and high-voltage, brake and welding. A number of specialized classrooms were also organized: locomotive industry, rolling stock and wagon economy, mechanization of handling works and applied mechanics, mathematics and theoretical mechanics, geodesy, graphics, the specialized classroom "Railways, stations and nodes", language classrooms, party education, physical education, military, as well as a radio station and a cinema. There was a library, the book fund of which in 1937 numbered more than 109 thousand books [5].

The growth of scientific work in the departments and laboratories led to the emergence of printed collections of works of the institute. The first collection was published in 1935, and a total of 14 were published before the war [5].

According to the Decision of the All-Union Committee of Higher Education, the institute was given the right to accept candidate's dissertations for further defence. Back in 1930, a postgraduate course was established in the educational institution in the following specialties:

"Locomotive industry", "Organization of movement on railway transport", "Organization of cargo works on railway transport".

In 1940-1941 academic year the first decade of activity of the Kharkiv Institute of Railway Engineers, which during this time became one of the largest railway higher educational institutions of the USSR was celebrated. There were already 12 professors in the highly qualified teaching staff; $46 \%$ of all teachers had academic degrees and academic titles [5].

Conclusions. The retrospective analysis of the activities of educational institutions that provided training for the future specialists in the transport industry showed that during the period (late XIX - early XX century), in connection with the development of scientific and technological progress in society there was a need for training of the future maritime and railway professionals. During this period, educational institutions were established, which actively developed in the system of professional training of transport specialists. The retrospective analysis showed that the path of formation and development of the system of professional training of the future transport specialists in educational institutions of Ukraine is complex, partly contradictory, due to the economic and historical-social context, on the one hand, and on the other - the complexity of the problem, as professional training 
of the specialists of the transport industry is a systemic and multi-vector phenomenon that combines the formation of value attitude to the profession, and the development of scientifictechnological progress is not possible without quality training of highly qualified personnel.

\section{Bibliography:}

1. Золотовська В.С. Комунікативна підготовка курсантів в історії розвитку морської освіти України. Наукові записки. Серія: Педагогічні науки. Випуск 159. 2017. С. 206-210.

2. І Історія університету. URL: https://kart.edu.ua/pro-universitet/history-uni.

3. Нагрибельний Я. А. Розвиток професійної освіти на Херсонщині у другій половині XIX століття - на початку 1920-х рр. : дис. ... канд. істор. наук: 07.00.01 / Чорноморський державний університет імені Петра Могили. Миколаїв, 2012. 240 с.

4. Нагрибельний Я. Розвиток системи морської освіти в Україні. Інноваційна педагогіка. Одеса: Видавничий дім «Гельветика», 2020. Вип. 22. Том 2. С. 25-30.

5. Нарис історії університету. URL: http://logoskiev.com.ua/books/hiit/014.pdf

6. Тимофєєва О. Я. Історія морської освіти в Україні та сучасні наукові підходи до формування соціально-комунікативної компетентності майбутніх судноводіїв. Вісник Національної академії Державної прикордонної служби України. Пед. науки. 2015. Вип. 5. URL: http://nbuv.gov.ua/UJRN/ Vnadped 2015518

7. Чорний О. В. Підготовка спеціалістів для морського флоту в Україні в останній чверті XVIII на початку XX ст.: автореф. дис. ... канд. іст. наук: 07.00.01 / Національний педагогічний університет імені М.П. Драгоманова. Київ, 2007. 16 с.

8. Шаргун Т. О. Концептуальний підхід до історичного досвіду професійної підготовки фахівців залізничного транспорту (XX - початок XXI століття). Науковий часопис НПУ імені М. П. Арагоманова. Серія 16: Творча особистість учителя: проблеми теорії і практики. 2015. Вип. 24. С. 80-85.

\section{References:}

1. Zolotovska, V. S. (2017). Komunikatyvna pidhotovka kursantiv v istorii rozvytku morskoi osvity Ukrainy [Communicative training of cadets in the history of maritime education in Ukraine]. Naukovi zapysky Seriia: Pedahohichni nauky, 159, 206-210 [in Ukrainian].

2. Istoriia universytetu [History of the university]. Retrieved from https://kart.edu.ua/prouniversitet/history-uni [in Ukrainian].

3. Nahrybelnyi, Ya. A. (2012). Rozvytok profesiinoi osvity na Khersonshchyni ts u druhii polovyni XIX stolittia - na pochatku 1920-kh rr. [The development of vocational education in the Kherson region in the second half of the XIX century - in the early 1920s]. (Candidate's thesis). Petro Mohyla Black Sea National University. Mykolaiv [in Ukrainian].

4. Nahrybelnyi, Ya. (2020). Rozvytok systemy morskoi osvity v Ukraini [Development of the marine education system in Ukraine]. Innovatsiina pedahohika, 22 (2), 25-30 [in Ukrainian].

5. Narys istorii universytetu [Essay on the history of the university]. Retrieved from http://logoskiev.com.ua/books/hiit/014.pdf [in Ukrainian].

6. Tymofieieva, O. Ya. (2015). Istoriia morskoi osvity $\mathrm{v}$ Ukraini ta suchasni naukovi pidkhody do formuvannia sotsialno-komunikatyvnoi kompetentnosti maibutnikh sudnovodiiv [The history of maritime education in Ukraine and modern scientific approaches to formation of social and communicative competence of the future navigators]. Visnyk Natsionalnoi akademii Derzhavnoi prykordonnoi sluzhby Ukrainy. Ped. Nauky, 5. Retrieved from http://nbuv.gov.ua/UIRN/ Vnadped 2015518 [in Ukrainian].

7. Chornyi, O. V. (2007). Pidhotovka spetsialistiv dlia morskoho flotu $v$ Ukraini $v$ ostannii chverti VIII na pochatku XX st. [Training of specialists for the navy in Ukraine in the last quarter of the XVIII early XX century]. (Extended abstract of Candidate's thesis). National Pedagogical Dragomanov University. Kyiv [in Ukrainian].

8. Sharhun, T. O. (2015). Kontseptualnyi pidkhid do istorychnoho dosvidu profesiinoi pidhotovky fakhivtsiv zaliznychnoho transportu (XX - pochatok XXI stolittia) [Conceptual approach to the historical experience of the railway transport specialists' vocational training $(\mathrm{XX}$ - beginning of the XXI century)]. Naukovyi chasopys NPU imeni M. P. Drahomanova. Seriia 16: Tvorcha osobystist uchytelia: problemy teorii i praktyky, 24, 80-85 [in Ukrainian]. 
Біницька К. М., orcid.org/0000-0002-2111-5275

Нагорний Я. В., orcid.org/0000-0003-2381-2194

Загородня $A$. A., orcid.org/0000-0003-2418-1670

\section{РОЗВИТОК СИСТЕМИ ПРОФЕСІЙНОЇ ПІДГОТОВКИ МАЙБУТНІХ ФАХІВЦІВ ТРАНСПОРТНОЇ ГАЯУЗІ В ЗАКЯАДАХ ОСВІТИ УКРАЇНИ (КІНЕЦЬ ХІХ - НА ПОЧАТКУ ХХ СТ.)}

У статті на основі теоретичних узагальнень розглянуто основні аспекти розвитку системи професійної підготовки майбутніх фахівців транспортної галузі в закладах освіти Украйни наприкінцці XIX - на початку XX сm.

Ретроспективний аналіз розвитку професійної підготовки майбутніх фахівців для транспортної галузі в Украйні в аналізований період був проведений на прикладі найбільш прогресивних та високооплачуваних на той час спеціальностей цієї галузі, а саме: підготовки фахівиів морської справи та залізничників.

Нами з'ясовано, щзо період кіния XIX - початку XX cm. - це час створення закладів освіти для підготовки майбутніх фахівців морської справи. Так, у цзей період на території України діяло понад 20 закладів освіти, в яких здійснювали професійну підготовку майбутніх моряків для військового та комерційного флоту. А одною з ключових ланок професійної освіти стали морські школи та училище далекого плавання, зокрема у Херсонській губернії. Узагальнено, щзо в період 1921-1941рр. професійну підготовку майбутніх фахівців для флоту здійснювали в корпусах (училищах), у яких пріоритетним напрямом професійної підготовки було визначено широку універсалізаціюю.

Узагальнено, що відбувся розвиток залізничного транспорту, особливо у зв'язку із побудовою на території Слобожанщини Курсько-Харківсько-Азовської залізниці, щзо в сою чергу потребував кваліфікованих фахівців різних професій, які так чи інакще взаємодіють із цієею галуззю. Відтак, м. Харків, важливий залізничний вузол, невдовзі став і центтом підготовки майбутніх фахівц̧ів-залізничників. Тому вже 1 грудня 1870 р. при ст. Харків відбулося відкриття залізничної школи з підготовки техніків, яку було реорганізовано в Харківське технічне залізничне училище. У 1917 р. Харківське технічне залізничне училище було реорганізовано в середню залізничну профтехнічну школу. На їі базі в 1921 р. було створено Харківський технікум шляхів сполучення механічної спеціальності з чотирирічним курсом навчання.

У 1920 р. на Південній залізниці почав роботу Експхуатацийний технікум із підготовки спецุiaхicmiв з експлуатаціï.

1 квітня 1926 р. у м. Харкові почали функцุіонувати курси спецціалістів для підготовки інженерів, які 17 серпня 1927 р., було перейменовано у Вищі технічні курси Народного комісаріату шляхів сполучення в Україні.

У 1929 р. три залізничні технікуми були об'єднані в один професійний технічний заклад - Харківський об'єднаний технікум шляхів.

Наприкінці 20-x - на початку 30-х рр. ХХ ст. економіка СРСР отримала стрімке піднесення, однак транспортна галузь не встигала за високими темпами промислового розвитку. Тому, 23 березня 1930 р. розпочав свою роботу Харківський інститут інженерів залізничного транспорту, який уже у 1940-1941 н.р. став одним із найбільших залізничних закладів вищзї освіти СРСР.

Отже, проведений ретроспективний аналіз діяльності закладів освіти, в яких здійснювали професійну підготовку майбутніх фахівців транспортної галузі, показав, що узв'язку з розвитком науково-технічного прогресу в суспільстві виникла потреба у підготовизі кваліфікованих майбутніх фахівцุів морської справи та залізничників. У цей період 


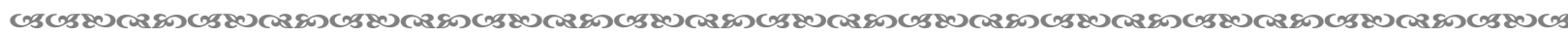
ПЕДАГОГІЧНИЙ АЛЬМАНАХ. - 2021. - ВИПУСК 49

us

були створені заклади освіти, які активно розвивалися у системі професійної підготовки фахівців транспортної галузі.

Ключові слова: професійна підготовка, майбутні фахівціі, транспортна галузь, моряки, залізничники.

Дата надходження статті: 07.052021 p.

Рецензент: доктор педагогічних наук, доцеент Кульчицьький В. Й.

У,ДК 378:656.2-051(477.7)(09)«20»(043.3)

DOI https://doi.org/10.37915/pa.vi49.280

Кузьменко В. В.,

orcid.org/0000-0002-5424-8234

\section{ПРОБЯЕМИ ПІДГОТОВКИ ФАХІВЦІВ ЗАЯІЗНИЧНОЇ ГАЯУЗІ (ПОЧАТОК ХХІ СТОЯІТТЯ)}

у статті проаналізовані проблеми підготовки фахівиів залізничного транспорту зі врахування різних аспектів підготовки (на рівні освіти, на рівні залізничної індустрії). Автором з'ясовано, щео на сьогоднішній день спецііальності у галузі залізничного транспорту, які пропонуються професійно-технічними навчальними закладами та закладами фахової передвищої освіти, не є достатньо популяризованими, а попит на залізничні спеціальності відносно низький. У статті виділено основні проблеми підготовки фахівиів залізничного транспорту: відсутність добре налагодженого зв'язку між освітою та роботодавиялин; низька престижність професійно-технічної освіти; відсутність або низький рівень наступності освітнвого процесу; брак оновлення професійних компетенціій в освітніх програмах тазапропоновано щляхи їх вирішення. Автор дійщов висновку, що освітні програми не встигають за розвитком науково-технічного прогресу, тому доцільним буде щорічне оновлення освітніх програм з урахуванням останніх тенденцій розвитку галузі. Для забезпечення налагодженого зв'язку між освітою та роботодавиями, Міністерство освіти інауки мае постійно аналізувати та моніторити розвиток ринку праці у галузі, робити необхідні зміни у держзамовленні, щоб забезпечити необхідну кількість фахівців для галузі. Аля підвищення престижності професійно-технічної освіти необхідно створити ряд умов, які б забезпечили притік абітурієнтів до закладів професійно-технічної та фахової передвищої освіти. Забезпечення наступності навчання надасть можливість майбутнім абітурієнтам отримувати безперервну освіту на всіх освітніх ланках. Більша увага мае приділятися формуванню м'яких компетенцій, щзо є конче необхіднии на сучасному ринку прациі. Підвищенню рівня володіння іноземною мовою може сприяти забезпечення закладів освіти необхіднии матеріалами, підручниками, посібниками, удосконалення підготовки викладачів іноземних мов за професійним спрямуванням, розвиток комунікативних компетенцій іноземними мовами тощо.

Ключові слова: підготовка, фахівці, залізничний транспорт, проблеми підготовки, професійно-технічна освіта, фахова передвища освіта, наступність, тверді та м'sкі навички.

Постановка проблеми. На початку XXI століття вивчення проблеми підготовки фахівців залізничної галузі набуло надзвичайної актуальності, оскільки ця галузь є однією 3 провідних для економічного розвитку України. Майбутній фахівець залізничного транспорту має відповідати певним професійним стандартам, мати високій рівень професійної підготовки, володіти твердими та м'якими навичками, які б допомагали йому бути конкурентноспроможним на українському та світовому ринку

*C) Кузименко В. В.

us 237 